\title{
KOMUNIKASI ANTARA PEMELUK AGAMA MINORITAS ISLAM DAN PENGANUT AGAMA MAYORITAS HINDU DI KABUPATEN KERANGASEM BALI
}

\author{
Drs. Hery Bambang Cahyono, M. Si. \\ Program Studi Ilmu Komunikasi - Fakultas Ilmu Sosial dan Ilmu Politik \\ Universitas Muhammadiyah Jember \\ Jalan Karimata No. 49, Telp. 0331- 336728, Jember 68121 \\ Email: heryb@unmuhjemner.ac.id
}

\begin{abstract}
Living together peacefully in a different society is not easy. Adherents of minority Muslims and majority Hindus in Karangasem Bali is a clear proof. They are able to work together to advance the region without meaningful conflict. Even though in Lampung Province there is still frequent friction between two religious adherents. An interesting problem is; how is the communication between these two elements of society and how to solve if there are problems that arise. The theory used is interpresonal communication by taking a role theory model. The method used is descriptive qualitative while the location stabilizes is At-Taqwiin Islamic Boarding School in Karangasem Regency, Bali. The result is that the community is accustomed to working in social, economic, political to social matters, while many religious issues are left to the kiai and religious teachers in the pesantren. The kiai has laid the foundation of harmonious communication and if there is a problem, the kiai always helps solve it.
\end{abstract}

Keywords: Communication, minority, majority

\begin{abstract}
Abstrak
Hidup berdampingan secara damai dalam masyarakat yang berbeda tidaklah mudah. Pemeluk agama Islam yang minoritas dan pemeluk agama Hindu yang mayoritas di Karangasem Bali merupakan suatu bukti nyata. Mereka mampu bekerja sama memajukan daerah tanpa adanya konflik yang berarti. Padahal di Propinsi Lampung sampai kini masih sering terjadi gesekan antar dua pemeluk agama. Masalah yang menarik adalah; bagaimanakah komunikasi antara dua elemen masyarakat tersebut serta bagaimanakah cara menyelesaikan kalau ada masalah yang timbul. Teori yang dipakai adalah komunikasi interpresonal dengan mengambil model teori peran. Metode yang digunakan adalah deskriptif kualitatis sedang yang mengabil lokasi adalah Pondok Pesantren AtTaqwiin di Kabupaten Karangasem Bali. Hasilnya adalah masyarakat sudah terbiasa bekerjasama dalam urusan sosial, ekonomi, politik hingga kemasyarakatan, sedangkan masalah agama banyak menyerahkan kepada kiai dan para ustad yang ada di pesantren. Kiai ternyata telah meletakan dasar komunikasi yang harmonis dan kalau ada masalah kiai selalu membantu menyelesaikan.
\end{abstract}

Kata Kunci : Komunikasi, minoritas may 
PENDAHULUAN

Pondok Pesantren merupakan lembaga pendidikan Islam yang tertua di Indonesia. Kata santri dalam khasanah kehidupan bangsa Indonesia dan khususnya umat Islam mempunyai dua makna. Pertama, menunjukan sekelompok peserta sebuah pendidikan pesantren atau pondok dan kedua, menunjukan akar budayanya sekelompok pemeluk Islam. Pesantren tidak saja sebagai lembaga pendidikan tetapi juga sebuah pusat budaya atau peradaban.

Menjadi menarik ketika pesantren itu berada di tengah-tengah masyarakat yang beragama lain yaitu Hindu di Kabupaten Karangasem Bali. Di satu sisi ada masyarakat yang minoritas sedang di sisi yang lain ada masyarakat yang mayoritas apalagi dalam bidang keyakinan yang berbeda. Selanjutnya pondok pesantren adalah sebuah lembaga Islam yang nyatanyata mengemban misi penyebaran agama Islam. Di samping itu pesantren adalah salah satu pusat budaya atau peradaban Islam yang tidak sekedar tempat pendidikan yang mempunyai kedudukan yang strategis.

Akan tetapi kenyataan menunjukkan kedua masyarakat mampu hidup berdampingan secara damai. Bahkan pesantren bisa hidup sampai saat ini dan berkembang semakin besar. Perkembangan itu ditandai dengan semakin banyaknya santri yang datang dari luar daerah dan banyaknya santri yang meraih prestasi. Maka adalah layak untuk mengaji masalah komunikasi antara pemeluk agama minoritas Islam dan penganut agama mayoritas Hindu di Kabupaten Kerangasem Bali.

\section{Rumusan Masalah}

Bagaimana komunikasi interpersonal antara pemeluk agama minoritas Islam dengan penganut agama mayoritas Hindu di Kabupaten Karangasem Bali

Bagaimana cara mengatasi hambatan komunikasi di Pondok Pesantren AtTaqwiim Karangasem?

\section{Tujuan Penelitian}

Untuk mengetahui komunikasi interpersonal antara pemeluk agama minoritas Islam dengan penganut agama mayoritas Hindu di Kabupaten Karangasem Bali

Untuk mengetahui hambatan komunikasi interpersonal antara pemeluk agama minoritas Islam dengan penganut agama mayoritas Hindu di Kabupaten Karangasem Bali.

\section{TINJAUAN PUSTAKA}

Teori Peran dalam Komunikasi

\section{Interpersonal}


Pada hakikatnya komunikasi interpersonal adalah komunikasi antara komunikator dan komunikan. Komunikasi ini paling efektif mengubah sikap, pendapat, atau perilaku seseorang. Komunikasi interpersonal bersifat dialogis. artinya, arus balik terjadi langsung. Komunikator dapat mengetahui tanggapan komunikan saat itu juga. Komunikator mengetahui tanggapan komunikan saat itu juga. Komunikator mengetahui secara pasti apakah komunikasinya positif, negatif, berhasil atau tidak. Jika tidak berhasil maka komunikator dapat memberi kesempatan komunikan untuk bertanya seluas-luasnya.

Menurut Cangara (2010) komunikasi Interpersonal merupakan proses komunikasi yang berlangsung antara dua orang atau lebih secara tatap muka. Komunikasi interpersonal memiliki karakteristik yaitu komunikasi terjadi dari satu orang ke orang lain, komunikasi berlangsung secara tatap muka dan isi dari komunikasi itu merefleksikan karakter pribadi dari tiap individu itu sebaik hubungan dan peran sosial mereka. Berdasarkan beberapa pengertian tersebut, maka dapat disimpulkan bahwa komunikasi interpersonal adalah proses komunikasi yang terjadi antara dua orang atau lebih secara langsung (tatap muka) dan terjadi timbal balik secara langsung pula baik secara verbal maupun non-verbal.

Agar masing-masing partisipan komunikasi dapat menyampaikan pesan secara efektif, maka masing-masing partisipan perlu memahami dan menangani berbagai komponen-komponen komunikasi yang mendukung jalannya proses komunikasi interpersonal. Komponen-komponen komunikasi interpersonal meliputi orang yang terlibat atau partisipan komunikasi, pesan yang dikirimkan atau diterima oleh masingmasing partisipan komunikasi, saluran yang digunakan, berbagai gangguan yang terjadi, konteks komunikasi, umpan balik yang dikirimkan sebagai bentuk tanggapan, serta efek yang ditimbulkan.

Teori peran dalam komunikasi interpersonal bisa dianalogikan seperti sebuah sandiwara. Seseorang di dalam masyarakat dalam mengaplikasikan perannya harus sesuai dengan "naskah masyarakat" yang sudah lama ada dan menjadi model dalam kehidupan. Komunikasi interpersonal akan efektif apabila pelaku-pelaku berperan sebagaimana naskah yang telah dibuat.Model ini menunjukan ada empat hal yang harus diperhatikan agar peran bisa 
dialkukan dengan baik. (Rakhmad, konflik peran yang kontradiktif, seperti Jalaluddin, 1996)

Pertama role ekpectation, yang mengacu pada kewajiban, tugas dan halhal yang berkatan dengan posisi tertentu dalam kelompok. Kiai dalam sebuah pesantren diharapkan sebagai rujukan perilaku seperti layaknya guru dalam sebuah sekolah. Seorang jenderal diharapkan menjadi tauladan seorang tentara yang tegas, kuat dan pemberani serta patuh pada komando. Suami diharapkan menjadi pelindung, pengayom, sekaligus pendidik bagi keluarganya. Kiai, guru yang berbuat jahat, jenderal yang penakut, suami yang keras adalah sososk yang tidak memenuhi ekspektasi peranan.

Kedua role demands, adalah tuntutan peranan adalah desakan sosial yang memaksa individu agar supaya memenuhi peran yang telah diberikan oleh masyarakatnya. Desakan sosial itu apabila tidak dipenuhi maka akan mendapatkan sanksi sosial. Tekanan inilah yang bisa memaksa atau menekan siapa saja yang tidak patuh pada tuntutan peranan.

Selanjutnya ketiga adalah role skills, yaitu kemampuan untuk memainkan perannya di dalam masyarakat yang biasanya terdiri dari kemampuan kognisi dan ketrampilan tindakan. Kempat adalah seorang bapak yang juga sebagai seorang polisi pada saat menangani perkara anaknya.

Model peranan dalam komunikasi interpersonal sangat sesuai untuk membedah komunikasi komunikasi pemeluk agama Islam yang minoritas dengan penganut agama mayoritas Hindu di Kabupaten Kerangasem Bali. Kiai dan para ustad sebagai tokoh sentral di pesantren mempunyai peran yang sangat besar dalam membina komunikasi yang harmonis serta menyelesaikan konflik yang ada.

\section{METODOLOGI PENELITIAN}

Penelitian ini menggunakan pendekatan deskriptif kualitatif. Lokasi penelitian akan dilakukan di Pondok Pesantren At-Taqwiim Karangasem Bali, karena pesantren ini ada di tengah-tengah masyarakat yang beragama Hindu. Sasaran penelitian ini di lakukan dengan pengasuh,santri dan masyarakat sekitar Pondok Pesantren. Tehnik penentuan data yang digunakan dalam penelitian ini adalah purposive sampling. Teknik pengumpulan data dengan cara observasi, wawancara dan dokumentasi. Sedangkan analisa data yang digunakan adalah analisa data kualitatif. 


\section{HASIL PENELITIAN DAN mempunyai nilai lebih dalam bidang PEMBAHASAN agama.}

\section{Gambaran lokasi penelitian}

Kabupaten Karangasem yang terletak di ujung Timur Pulau Bali merupakan salah satu dari 9 Kabupaten/Kota yang ada di Provinsi Bali. Batas wilayah kabupaten tersebut adalah sebagai sebagai berikut: Sebelah Utara - Laut Jawa,Sebelah Selatan - Samudera Indonesia,Sebelah Barat - Kabupaten Klungkung, Bangli, Buleleng,Sebelah Timur - Selat Lombok. Secara geografis Kabupaten Karangasem berada pada posisi 8000'00'8041'37,8''Lintang Selatan dan 115035'9,8'- 115054'8,9''Bujur Timur. Luas Kabupaten Karangasem adalah $839,54 \mathrm{Km}$ atau 14,90 \% dari luas Provinsi Bali $(5.632,86 \mathrm{Km})$. Dari seluruh luas wilayah tersebut, sekitar 7.070 Ha. $(8,42$ \%) merupakan lahan persawahan, sedangkan bukan lahan sawah76.884 Ha $(91,58 \%)$.

Pondok pesantren At-Taqwiin berdiri pada tahun 1994, dengan segala fasilitas yang minim . Fasilitas gedung dan tenaga pengajar serta asrama santri hanya sekedar berdiri. Setahun pertama merupakan perjuangan paling berat untuk mencari santri dan juga mengurusnya. Apalagi mencari guru juga susah karena harus

Pada saat itu jumlah fasilitas dan tenaga pengajar sangat minim hanya dari kalangan keluarga besar yang memiliki pendidikan agama yang baik sehingga pada saat itu pengajar semua dari bagian keluarga saat itu pun jumlah santri terbilang masih sedikit jadi lebih mudah di tangani dengan 3 orang pengajar. Kemudian pondok pesantren mulai melebarkan sayap seperti membangun cabang-cabang pondok pesantren AtTaqwiim di desa-desa tetangga yang tidak mumpuni untuk pergi langsung ke pondok pesantren.

Tahun 2001 perkembangan santri mulai berkembang pesat dari tahun-tahun sebelumnya dan yang sangat berharga adalah mulai dipercayai masyarakat Karangasem. Proses belajar mulai tertata dan santri mulai bisa berprestasi. Santri mulai mendapatkan fasilitas terutama untuk asrama. Berbagai ajang lomba yang selalu diikuti pondok untuk melatih kemampuan santri bersaing dengan pondok pesantren selain lain itu untuk mengenalkan pondok pesantren ke masyarakat luas. Tidak diragukan meskipun pondok pesantren berada jauh dari perkotaan mampu bersaing dengan 
pondok-pondok luar dalam urusan prestasi.

Bersaing dengan pondok pesantren luar merupakan hal yang biasa bagi pondok pesantren. Pondok Pesantren AtTaqwiin mempunyai mempunyai tiga unggulan yang mampu bersaing sampai ranah nasional. Pertama bagi yang berhasil tidak tanggung-tanggung selalu ada hadiah dari pondok kedua ada beasiswa dan yang ketiga akan dibiayai bila menempuh ilmu di pondok yang lain.

Semakin bergerak maju pondok pesantren terus menambah tenaga pengajar dan fasilitas untuk santri . Seperti pondok pada umumnya keluarga merupakan kekuatan inti dalam membangun pondok agar berkembang. Kiai dengan keluarganya kini terus berupanya maju dan juga masyarakat sekitar yang mendukung.

Masyarakat semakin sadar bahwa keberadaan pondok pesantren merupakan lembaga yang sangat berarti di Karangasem. Mengingat Bali adalah masyarakat yang beragama Hindu, sedang umat Islam tentu saja perlu lembaga untuk mendidik anak-anaknya agar sesuai dengan agamanya yaitu Islam.

Perkembangan terakhir pondok pesantren tersebut telah memiliki banyak sekali sekolah-sekolah formal, yaitu: Raudatul Atsfal (RA/TK), Madrasah
Ibtidayah (MI), Madrasah Tasanawiyah (MTs), Madrasah Aliyah (MA), TPQ dan Madin, Program kerja Paket, Majlis Taklim, Kopontren dan Panti Asuhan. Di samping itu jumlah santri juga semakin banyak dan dari aspek asal santri juga mulai beragam.

\section{Hasil Penelitian}

Komunikasi interpersonal antara pemeluk agama minoritas Islam dengan penganut agama mayoritas Hindu di Karangasem Bali

Pondok Pesantren At-Taqwiim yang sudah berdiri sejak dua puluh tahun dimana dalam peroses berdirinya berbeda dengan pesantren lain. Pondok Pesantren At-Taqwiim berdiri di tengah-tengah masyarakat nonmuslim yang masih kental dengan tradisi dan adat budaya yang bersumber dari ajaran Hindu terutama Hindu Bali. Sekalipun demikian pesantren tersebut mampu berkemunikasi dengan baik dan berkembang dengan pesat. Adapun komunikasi interpersonal itu dapat diuraikan sebagai berikut:

\section{Etika Komunikasi}

Etika komunikasi yang bersumber dari agama Islam yang minoritas tentu saja mempunyai perbedaan dengan masyarakat Karangasem yang beragama Hindu. Akan tetapi sebagai masyarakat Indonesia etika komunikasi itu banyak persamaannya. 
Kiai dan para ustad pesantren selalu menekankan untuk menghargai etika komunikasi warga setempat yang beragama Hindu. Maimunah menyampaikan bahwa kita harus mengakui adanya perbedaan berkaitan dengan agama, maka kita saling menghargai.

Etika itu akhirnya juga dapat memilah mana masalah yang bisa dikomunikasikan dan mana yang harus hati-hati dalam menyampaikan. Masalah-masalah di luar agama lebih bebas untuk dibicarakan akan tetapi masalah keyakinan atau agama harus sangat hati-hati. Bila masalah sosial siapapun bisa berbicara akan tetapi dalam masalah hanya kiai dan tokoh-tokoh pesantren yang lebih berkompeten. Apalagi dalam Islam sudah jelas bahwa "Bagimu agamamu, bagiku agamaku".

Disamping itu etika komunikasi juga berkaitan dengan tata krama dalam bergaul atau berkomunikasi. Menghormati yang tua menghargai yang muda sudah menjadi tradisi di daerah ini. Apalagi terhadap tokoh adat dan tokoh agama sejak jaman dulu sudah mendarah daging atau menjadi tradisi. Berikut penjelasan dari kiai Ali Musbah selaku pengasuh dan pemimpin di Pondok Pesantren At-Taqwiim.

"Ketika pengasuh berkomunikasi dengan santri bagaimana pengasuh harus bisa memberikan contoh atau keteladanan dalam komunikasi yang baik yang ramah yang santun sehingga bisa di contoh oleh para santri kemudian etika berkomunikasi santri dan pengasuh karna ini adalah lembaga pendidikan yang berbasis islam tentu yang di kedepankan adalah soal tata kerama ahlak qulkarimah sehingga saat santri berkomunikasi dengan pengasuh mereka berkomunikasi dengan penuh kesopanan dan tata kerama sebagaimana yang sudh di ajarkan di pesantren, kedekatan pengasuh dengan santri di dunia pesantren ketika kita ingin mengajarkan ahlak kesopana kepada santri maka ada ada sesuatu yang pelu menjadi perhatian dari seorang pengasuh tentu menempatkan dirinya sebagai seorang Ayah, Bapak, Orangtua kepada anak-anaknya sehingga kedekatan terjalin kemudian santri menjadi diperhatikan dan ada keterbukaan dari pada ketika pengasuh menjaga jarak dengan santri pada hal-hal tertentu memang perlu dijaga supaya bagaimana muroah sebagai pengasuh tetap terjaga di Pondok Pesantren”.

Dari gambaran di atas maka aspek etika komunikasi selalu dijaga oleh masyarakat terutama dari pihak pesantren.

\section{Peran}

Salah satu pernyataan yang sangat menarik dalam komunikasi antara pemeluk agama Islam yang minoritas dan penganut agama Hindu yang mayoritas adalah yang disampaikan oleh informan yang bernama Erno. Erno menyatakan bahwa dalam keseharian dia hanya 
berkomunikasi yang berkaitan dengan masalah sosial-kemasyarakatan terutama yang berkaitan dengan kerja atau yang bersifat ekonomi. Seperti penuturannya sebagai berikut :

"Berkomunikasi dengan masyarakat muslim maupun nonmuslim merupakan suatu hal yang lumrah disekitar Pondok Pesantren AtTaqwiim namun tetap ada batasanbatasan jika bersama masyarakat muslim kami lebih dekat dalam urusan kerja sama, namun dengan masyarakat nonmuslim kami lebih bijak menghadapi perbedaan agama, melakukan komunikasi yang baik serta bentuk toleransi yang tetap kami junjung tinggi bersama masyarakat sekitar karan di desa bukit ini pada umumnya banyak yang beragama nonmuslim kita di Pondok Pesantren At-Taqwiim lebih mengalah dalam urusan kegiatan yang bersamaan terjadi, saling menghargai apapun perbedaan yang dimiliki"

Rupanya Erno adalah hanya salah satu dari sekian banyak masyarakat minoritas Islam di tempat tersebut. Bila dilihat dari teori peran, Erno ingin bereperan sesuai dengan kedudukannya sebagai masyarakat biasa. Sedang masalah yang ada kaitanya dengan agama menyerahkan kepada kiai dan para ustad di pondok pesantren. Erno dan masyarakat kebanyakan tau akan posisi dan perannya, apabila mengambil peran dalam masalah agama menjadi tidak sesuai. Ibaratnya bermain drama bila menyampaikan masalah agama akan bertentangan dengan naskah atau kebiasaan masyarakat.

\section{Kerjasama}

Masyarakat paham bahwa di luar agama masih banyak sekali masalah sosial kemasyarakatan yang bisa dijadikan jembatan untuk membina kerjasama. Seperti masalah keamanan pembangunan desa, kerjasama dalam pendidikan dan masih banyak sekali. Bahkan kerjasama dalam bidang politikpun masih bisa dilakukan. Sebab ketika PILKADA kedua masyarakat tersebut harus saling membantu untuk memilih pimpinan daerah. Apalagi dalam bidang ekonomi tentu saja tidak bisa bekerja sendirisendiri. Bagi masyarakat di Karangasem merupakan hal biasa untuk bekerjasama.

Berikut penjelasan dari Ibu Maimunah sebagai guru dan ustazah di Pondok Pesantren At-Taqwiim.

"Menjaga hubungan baik tentu merupakan suatu hal yang harus kami pertahankan baik itu dengan masyarakat muslim atau nonmuslim kami lakukan dengan menjaga toleransi, berkomunikasi baik saat akan diadakan kegiatan,saling berbagi dalam sebuah perayaan menjalin kerjasama dalam even-even tertentu serta berkolaborasi dengan masyarakat, Pondok Pesantren AtTaqwiim menampilkan adat budaya yang ada di pesantren dan masyarakat pun demikian sesuai 
kesepakatan bersama" (wawancara Ibu Maimunah juma't 03-05-2019 dilakukan di Pondok Pesantren AtTaqwiim)

Berikut penjelasan dari bapak Kamarudin sebagai masyarakat kepala bagian desa di Karangasem :

"Masyarakat yang besar tentu memiliki hubungan baik dengan Pondok Pesantren At-Taqwiim saling mendukung kegiatan yang di lakukan di Pondok Pesantren maupun kegiatan di masyarakat sebagai tujuan baik sebab itu dapat memberikan keuntungan besar untuk masyarakat sekitar, kerjasama yang sampai saat ini tetap terjalin dengan Pondok Pesantren At-Taqwiim adanya lapangan pekerjaan baru untuk masyarakat sekitar" (wawancara Bapak Kamarudin rabu 01-05-2019 dilakukan di rumah Bapak Kamarudin)

Dari paparan diatas hubungan baik dan kerjasama yang dilakukan Pondok Pesantren At-Taqwiim dengan masyarakat terlihat sedikit berbeda jika Pondok Pesantren At-Taqwiim lebih mengedepankan sifat dan hubungan baik berbeda masyarakat mereka lebih mengutamakan kerjasama yang baik dengan pihak Pondok Pesantren AtTaqwiim untuk kesejahteraan masyarakat sekitar dalam urusan lapangan pekerjaan dan usaha yang dimiliki masyarakat. Meskipun terlihat berbeda mereka tetap memiliki hubungan baik dan kerjasama yang terus terjalin sampai saat ini.

\section{Cara mengatasi hambatan komunikasi}

Dalam proses komunikasi tentu memiliki hambatan yang dapat menghambat proses komunikasi apalagi komunikasi yang dilakukan tidak hanya dengan satu atau dua orang saja melebihi dalam suatu kelompok masyarakat, hambatan bisa berupa tidak jelasnya informasi yang diberikan, terjadinya kesalah pahamaan hambatan yang berasal dari orang yang menyampaikan pesan sehingga dapat mengakibatkan konflik dalam komunikasi yang di lakukan oleh Pondok Pesantren At-Taqwiim dengan masyarakat suatu intraksi yang terjadi akibat adanya ketidak sesuaian antara dua pendapat yang berpengaruh ada pihakpihak yang terlibat dalam komunikasi dan akan berpengaruh positif maupun pengaruh negatif sehingga dibutuhkan penyelesaian dari pihak Pondok Pesantren At-Taqwiim dan masyarakat. Berikut penjelasan dari Bapak Erno sebagai guru dan ustad di Pondok Pesantren AtTaqwiim.

"Saat berkomunikasi tak jarang dari pihak Pondok Pesantren At-Taqwiim mengalami hambatan dengan masyarakat seperti kesalah informasi yang diterima, cara pandang masyarakat kepada Pondok Pesantren yang berbeda-beda hal tersebut yang sering memicu terjadinya sebuah 
konflik meskipun terlihat kecil dan biasa saja tetapi tetap dari pihak Pondok Pesantren At-Taqwiim menyelesaikan dengan masyarakat dengan mendatangi masyarakat yang mengalami konflik, menjelaskan permasalahan, dan meminta maaf atas kesalahan dan ketidaknyamanan" (wawancara Bapak Erno senin 15-04-2019 dilakukan di Pondok Pesantren AtTaqwiim )

Berikut penjelasan dari Bapak Achmad Suhaimi sebagai Tuan guru dan penasehat di Masyarakat.

"Sebagai tuan guru di masyarakat hambatan komunikasi dengan Pondok Pesantren At-Taqwiim tak jarang sering terjadi namun selama inihambatan dan konflik tidak terlalu besar yah seperti kesalah pahaman, kegaduhan yang dibuat oleh para santri yang mengakibatkan masyarakat merasa terganggu,tidak sampai terjadi konflik besar sebab dari Pondok Pesantren At-Taqwiim segera menyelesaikan konflik-konflik kecil sehingga tidak menjadi permasalanah yang besar antara Pondok Pesantren At-Taqwiim dengan masyarakat".

Dari pemaparan di atas hambatan komunikasi yang terjadi antara pondok dengan masyarakat sekitar tak jarang diakibatkan dari kesalah pahaman informasi dan cara pandang yang berbeda antara dua belah pihak ketidak nyamanan yang di lakukan dari pihak Pondok Pesantren At-Taqwiim yang kadang memicu masyarakat untuk menegur dan memberikan keritik. Penyelesaian yang lakukan oleh kedua belah pihak pun mendorong adanya pengurangan dari sebuah masalah dan konflik yang terjadi,kesepakatan menyelesaikan dari hal-hal yang kecil, dan fokus menyelesaikan permasalahan agar tidak mennjadi suatu konflik yang besar.

\section{Kesimpulan}

Komunikasi antara pemeluk agama minoritas Islam dan pemeluk agama mayoritas Hindu di Karanganyar Bali dilakukan dengan memperhatikan etika komunikasi. Pesan mana sajakah yang bisa dijadikan bahan atau pesan dalam pergaulan dan pesan mana yang harus dihindari. Masyarakat banyak yang memilih untuk berkomunikasi hanya yang banyak bersangkutan dengan pekerjaan. Kedua pemeluk agamanya yang berbeda tersebut juga bekerjasama dalam aspek sosial, seperti ekonomi, budaya, hingga politik. Bila menyangkut masalah agama banyak menyerahlan kepada kiai dan ustad yang ada di Pondok Pesantren At-Taqwiin. Kiai di pondok pesantren mempunyai peran yang besar dalam meletakan dasar-dasar komunikasi di daerah tersebut. 
DAFTAR PUSTAKA

Bungin, Burhan. 2000. Metodelogi Penelitian Kuantitatif. Jakarta : Kencana.

Budyatna, Muhammad. 2014. Komunikasi Antar-Pribadi, Jakarta : Kencana.

Cangara, Hafied. 2010. Pengantar Ilmu Komunikasi. Jakarta : grafindo persada.

Moleong, Lexy J. 1989. Metode Penelitian Kualitatif. Bandung : Remaja Rosdakarya.
Mulyana, Dedy. 2000. Ilmu Komunikasi Suatu Pengantar. Bandung : PT Remaja Rosdakarya.

Rahmat, Jalaludin, M.Sc. 1996. Pisikologi Komunikasi. Bandung : PT Rosdakarya.

Suranto. 2000. Komunikasi Interpersonal. Jakarta : Geraha Ilmu.

Supratiknya. $1995 . \quad$ Komunkasi Antarpribadi Tinjauan Psikologis. Yogyakarta : Kasinius. 